\title{
Bio- efficacy of Different Herbicides in Broad Spectrum Weed Management for Chickpea
}

\author{
Devendra Singh ${ }^{1}$, S. Pazhanisamy ${ }^{1}$, Sunil Kumar ${ }^{2 *}$, \\ Amrendra Kumar ${ }^{2}$ and Sai Linga Reddy ${ }^{1}$
}
${ }^{1}$ Department of Agronomy, Dr. Rajendra Prasad Central Agricultural University, Pusa, Bihar-848 125, India
${ }^{2}$ Department of Agronomy, Tirhut College of Agriculture (Dr. Rajendra Prasad Central Agricultural University) Dholi, Bihar-843121, India

*Corresponding author

\section{A B S T R A C T}

\begin{tabular}{l}
\hline Ke y w o r d s \\
Broad-spectrum, \\
Pendimethalin, \\
Bio-efficacy, CS \\
Formulation and \\
Partial budgeting \\
\hline Article Info \\
\hline $\begin{array}{l}\text { Accepted: } \\
\text { 15 February } 2020 \\
\text { Available Online: } \\
10 \text { March 2020 }\end{array}$ \\
\hline \hline
\end{tabular}

A field experiment was conducted during rabi seasons of 2014-15 and 2015-16 at research farm of TCA, Dholi, Muzzafarpur a campus of Dr Rajendra Prasad Central Agricultural University, Pusa, Samastipur, Bihar (India) to evaluate the bio- efficacy of different herbicides in broad spectrum weed management for chickpea. Ten treatments were tested in randomized block design with three replications. Among the herbicides pendimethalin CS formulation (1 kg/ha), PE + One hoeing 35 DAS recorded significantly higher seed yield $(1348.50 \mathrm{~kg} / \mathrm{ha})$, straw yield(1600.33 kg/ha)lower weed dry weight $\left(1.34 \mathrm{~g} / \mathrm{m}^{2}\right)$, lower weed index (5.91\%), higher weed control efficiency (73.28\%) and more added returns (Rs. 64280/ha) than all other herbicidal treatments. Present investigation revealed that pendimethalin CS formulation ( $1 \mathrm{~kg} / \mathrm{ha}), \mathrm{PE}+$ One hoeing 35 DAS could be used effectively as an alternative for controlling most of the weeds and obtaining optimum seed yield of chickpea during rabi season in Bihar.

\section{Introduction}

Chickpea (Cicer arietinum L.) belongs to genus Cicer, family Fabaceae, and sub-family Papilionaceae. India is the largest producer of chickpea in the world covering $9.51 \mathrm{mha}$ area and producing 8.83 MT of grain with an average productivity of $929 \mathrm{~kg} \mathrm{ha}^{-1}$.In Bihar chickpea is cultivated in an area of 0.59 million hectare with annual production 0.64 
million tonnes and average productivity is $1087 \mathrm{~kg} \mathrm{ha}^{-1}$ (Anonymous, 2018). The yield of this crop is adversely affected due to many factors but among those, weed infestation is very important (Singh et al., 2008). Chickpea is a poor competitor to weeds because of its slow growth rate and limited leaf area development at early stages of crop growth. The critical period of crop-weed competition in chickpea usually falls between 30-45 days after sowing (Goud et al., 2013). In addition to slow initial crop growth, wider crop spacing also facilitates crop-weed competition which poses a serious limitation to chickpea production, and thus, adversely affecting yield potential (Bhalla et al., 1998). Weeds also pose negative effect on main crop by competing with the crop plants for soil moisture, nutrients, space and sunlight (Patel et al., 2006). Chickpea is being grown in both rainfed and irrigated systems, where weed control is a major obstacle to profitable production. Due to high weed infestation, chickpea producers experienced decreased profits in recent years. Further, the input costs have also increased more rapidly than crop prices. In the absence of any suitable herbicides, majority of Indian farmers usually do manual weeding that is time consuming, labour-intensive and higher wages increases cost of cultivation. If this operation is delayed, it will not be effectively preventing adverse effect of the weeds on crop yield. The use of appropriate herbicides can eliminate this early weed competition prevent yield losses and cost of production. Herbicides are selective, cost effective, and easy to apply, and offer flexibility in application time (Hoseiny and Jagannath, 2011). The current trend and future development of intensive agriculture are likely to seek the help of chemicals as an effective weed control measures and replace the conventional method of weed control. Whereas use of herbicides had revolutionized weed control, reduce the cost of production.

\section{Materials and Methods}

A field experiment was conducted at research farm of TCA, Dholi, Muzzafarpur a campus of Dr Rajendra Prasad Central Agricultural University, Pusa, Samastipur, Bihar (India) for two consecutive rabi seasons of 2014-15 and 2015-16 to evaluatebio- efficacy of different herbicides in broad spectrum weed management for chickpea. Dholi Farm is situated in North Bihar on the southern and Western bank of the river Burhi Gandak at $25^{\circ} 59^{\prime}$ North latitude and $85^{\circ} 75^{\prime}$ East longitudes with an altitude of $52.9 \mathrm{~m}$ above mean sea level (MSL). It enjoys a humid subtropical climate, influenced greatly by southwest monsoon. The main characteristic of the climate is hot-dry summer and cold winter. The rainfall received during crop seasons were $33 \mathrm{~mm}$ and $8.6 \mathrm{~mm}$ during 2014-15 and 2015-16, respectively. Whereas the average maximum and minimum temperatures of $2014-15$ and $2015-16$ were $24.78^{\circ} \mathrm{C}, 16.65^{\circ} \mathrm{C}$, $27.60^{\circ} \mathrm{C}$ and $13.30^{\circ} \mathrm{C}$ respectively. The soil of the experimental site was sandy loam texture having high $\mathrm{pH} 8.2, \mathrm{EC} 1.01 \mathrm{dSm}^{-1}$, medium Organic carbon $0.45 \%$, low available $\mathrm{N}$ (207.00 $\left.\mathrm{kg} \mathrm{ha}^{1}\right)$, medium available $\mathrm{P}(16.80 \mathrm{~kg}$ $\left.\mathrm{ha}^{-1}\right)$ and normal $\mathrm{K}\left(108.50 \mathrm{~kg} \mathrm{ha}^{-1}\right)$. The experiment was laid out in a Randomized Block Design with three replicationsand the treatments were consist of ten different weed management practicesviz., Pendimethalin EC formulation $(1 \mathrm{~kg} / \mathrm{ha}), \mathrm{PE}+$ One hoeing 30 DAS $\left(\mathrm{T}_{1}\right)$, Pendimethalin CS formulation (1 $\mathrm{kg} / \mathrm{ha}), \quad \mathrm{PE} \quad\left(\mathrm{T}_{2}\right), \quad$ Pendimethalin CS formulation(1 kg/ha), PE + One hoeing 35 DAS ( $\left.\mathrm{T}_{3}\right)$, Fenoxapropethyle @ 60 g/ha POE at 30 DAS $\left(\mathrm{T}_{4}\right)$, Pendimethalin $30 \mathrm{EC}$ formulation + Imagethapyr 2\% (ready mix combination) @ $1 \mathrm{~kg} / \mathrm{ha} \quad \mathrm{PE} \quad\left(\mathrm{T}_{5}\right)$, Pendimethalin 30 EC formulation + Imagethapyr 2\% (ready mix combination) @ $1 \mathrm{~kg} / \mathrm{ha} \mathrm{PE}+$ one hoeing at $30 \mathrm{DAS}\left(\mathbf{T}_{\mathbf{6}}\right)$, Pendimethalin CS formulation @ 1kg/ha, PE + Imazethapyr 2\% (tank mix combination@ 
$1 \mathrm{~kg} / \mathrm{ha})\left(\mathrm{T}_{7}\right)$, One hoeing/hand weeding at 30 DAS $\left(\mathrm{T}_{8}\right)$, Weed free $\left(\mathrm{T}_{9}\right)$ and Weedy check $\left(\mathrm{T}_{10}\right)$. The variety of HK-2seeds was sown in line manually with $30 \times 10 \mathrm{~cm}$ spacing in the well prepared field. Pre-sowing irrigation was given before sowing. In nutrient management, entire dose of nitrogen $(20 \mathrm{~kg} / \mathrm{ha})$ phosphorus (45 $\left.\mathrm{kg} \mathrm{ha}^{-1}\right)$, potassium (20 $\left.\mathrm{kg} \mathrm{ha}^{-1}\right)$ and sulphur $(20 \mathrm{~kg} / \mathrm{ha})$ were applied as a basal. Three hand weedings were done in weed free plots, the pre- and post-emergence herbicidal treatments were imposed as per schedule. Data for individual years were pooled and statistically analyzed as per the procedure given by Gomez and Gomez (1984) for randomized block design then, weed index and weed control efficiency (WCE) was calculated by the respective formula.

\section{Results and Discussion}

\section{Effect on grain and straw yield}

From the study, the data clearly revealed that weed management practices significantly influenced the grain and straw yield of chickpea during both the years. Among the treatments, application of pendimethalin CS formulation (1 kg/ha), PE + One hoeing 35 DAS and pendimethalin $30 \mathrm{EC}$ formulation + imazethapyr 2\% (ready mix combination)@ $1 \mathrm{~kg} / \mathrm{ha} \mathrm{PE}+$ one hoeing at 30 DAS had significantly higher grain and straw yield than other treatments, also these two treatments were on par with weed free check, where the maximum grain yield was recorded (Table 1). It is mainly due to the complete elimination of weeds throughout the crop growth which enabled minimum competition and causing better plant growth along with higher number of branches and number of pods per plant during first and second year. Higher seed and straw yield in these treatments could be occasioned to more number of branches and number of pods per plants due to lesser competition deliverable by weeds for light, water and nutrients etc., which resulted in more uptake of nutrients, water and produced more photosynthates. Similar results had also been reported by Ratnam and Reddy (2011), Pedde et al., (2013) and Rathod et al., (2016). The minimum grain and straw yield was recorded under weedy check which was significantly lower than other weed management practices (Table 1).

Table.1 Effect of different weed management practices on grain \& straw yield $(\mathrm{kg} / \mathrm{ha})$

\begin{tabular}{|c|c|c|c|c|c|c|}
\hline Treatments & \multicolumn{3}{|c|}{$\begin{array}{c}\text { Grain yield } \\
\text { (kg/ha) }\end{array}$} & \multicolumn{3}{c|}{$\begin{array}{c}\text { Straw yield } \\
\text { (kg/ha) }\end{array}$} \\
\hline & $\mathbf{2 0 1 4 - 1 5}$ & $\mathbf{2 0 1 5 - 1 6}$ & Pooled & $\mathbf{2 0 1 4 - 1 5}$ & $\mathbf{2 0 1 5 - 1 6}$ & Pooled \\
\hline $\mathbf{T}_{\mathbf{1}}$ & 939 & 1245 & 1100.00 & 1103 & 1470.66 & 1288.67 \\
\hline $\mathbf{T}_{\mathbf{2}}$ & 978 & 889 & 921.50 & 1179 & 1027.66 & 1079.17 \\
\hline $\mathbf{T}_{\mathbf{3}}$ & 1075 & 1633 & 1348.50 & 1254 & 1973.33 & 1600.33 \\
\hline $\mathbf{T}_{\mathbf{4}}$ & 790 & 889 & 839.83 & 969 & 1042.33 & 996.00 \\
\hline $\mathbf{T}_{\mathbf{5}}$ & 922 & 1522 & 1219.83 & 1080 & 1783.66 & 1443.00 \\
\hline $\mathbf{T}_{\mathbf{6}}$ & 1084 & 1589 & 1329.67 & 1193 & 1795 & 1492.50 \\
\hline $\mathbf{T}_{\mathbf{7}}$ & 958 & 1033 & 980.00 & 1005 & 1193.33 & 1079.83 \\
\hline $\mathbf{T}_{\mathbf{8}}$ & 863 & 1067 & 966.00 & 897 & 1237.66 & 1068.33 \\
\hline $\mathbf{T}_{\mathbf{9}}$ & 1106 & 1733 & 1437.67 & 1144 & 1995 & 1587.33 \\
\hline $\mathbf{T}_{\mathbf{1 0}}$ & 632 & 578 & 608.83 & 690 & 700.66 & 69.83 \\
\hline $\mathbf{S E d}_{\mathbf{S E}}$ & 43.51 & 198.07 & 109.83 & 49.90 & 217.42 & 118.28 \\
\hline $\mathbf{C D} \mathbf{0 . 0 5})$ & 89.28 & 416.15 & 230.74 & 102.39 & 456.80 & 248.50 \\
\hline
\end{tabular}


Table.2 Effect of different weed management practices on weed dry matter $\left(\mathrm{g} / \mathrm{m}^{2}\right)$, weed index $(\%)$ and (WCE \%)

\begin{tabular}{|c|c|c|c|c|c|c|c|c|c|}
\hline \multirow[t]{2}{*}{ Treatments } & \multicolumn{3}{|c|}{$\begin{array}{l}\text { Weed dry weight } \\
\text { (g/m at } 60 \text { DAS) }\end{array}$} & \multicolumn{3}{|c|}{$\begin{array}{l}\text { Weed Index } \\
(\%)\end{array}$} & \multicolumn{3}{|c|}{$\begin{array}{l}\text { Weed Control Efficiency } \\
(\%)\end{array}$} \\
\hline & 2014-15 & $2015-16$ & Pooled & 2014-15 & 2015-16 & Pooled & 2014-15 & 2015-16 & Pooled \\
\hline $\mathbf{T}_{1}$ & 1.81 & 1.81 & 1.81 & 14.86 & 28.20 & 22.20 & 61.22 & 67.66 & 64.08 \\
\hline $\mathbf{T}_{2}$ & 2.367 & 3.86 & 3.18 & 10.80 & 47.32 & 31.74 & 48.63 & 33.65 & 39.02 \\
\hline $\mathbf{T}_{3}$ & 1.35 & 1.35 & 1.34 & 2.12 & 5.18 & 5.91 & 70.82 & 76.23 & 73.28 \\
\hline $\mathbf{T}_{4}$ & 3.01 & 3.49 & 3.25 & 28.22 & 49.17 & 39.94 & 34.85 & 37.96 & 35.61 \\
\hline $\mathbf{T}_{5}$ & 3.49 & 2.15 & 2.85 & 16.08 & 11.35 & 15.39 & 24.05 & 60.34 & 40.53 \\
\hline$T_{6}$ & 2.15 & 2.55 & 2.43 & 1.30 & 7.97 & 7.02 & 54.38 & 55.08 & 52.57 \\
\hline $\mathbf{T}_{7}$ & 2.74 & 3.33 & 3.13 & 12.74 & 40.29 & 29.52 & 40.45 & 40.04 & 37.58 \\
\hline $\mathbf{T}_{8}$ & 1.77 & 2.95 & 2.38 & 21.65 & 39.05 & 31.61 & 61.59 & 49.00 & 54.34 \\
\hline $\mathbf{T}_{9}$ & 0.55 & 0.45 & 0.49 & 0.00 & 0.00 & 0.00 & 88.07 & 91.98 & 90.21 \\
\hline $\mathbf{T}_{10}$ & 4.7 & 5.8 & 5.19 & 42.51 & 66.89 & 55.32 & 0.00 & 0.00 & 0.00 \\
\hline SEd & 0.26 & 0.50 & 0.31 & 4.00 & 11.5 & 6.73 & 5.79 & 8.44 & 5.68 \\
\hline $\mathrm{CD}(\mathrm{p}=0.05)$ & 0.54 & 1.07 & 0.66 & 8.21 & 24.2 & 14.14 & 11.89 & 17.73 & 11.93 \\
\hline
\end{tabular}

Table.3 Partial budgeting analysis

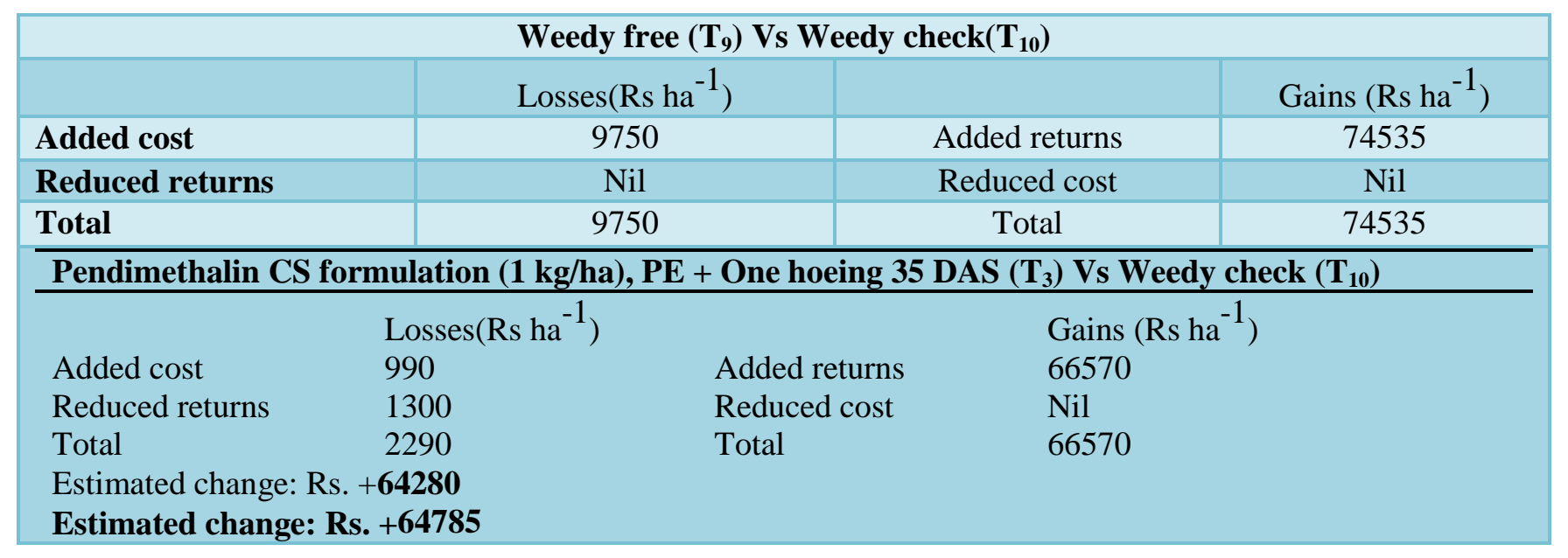




\section{Effect on weed parameters}

All the weed management treatments significantly suppressed the weeds than weedy check. Among the weed management practices weed free (check) and treatment pendimethalin CS formulation $(1 \mathrm{~kg} / \mathrm{ha}), \mathrm{PE}+$ One hoeing 35 DAS were recorded similarly lowest weed dry weight, weed index and highest weed control efficiency which were significantly effective over weedy check treatment in respect of weed suppressing ability (Table 2). The same results were reported by Ratnam and Reddy (2011) and Rathod et al., (2016).

\section{Partial budgeting analysis}

In the present investigation partial budgeting was undertaken as an economical tool to analyze the relative economics of various weed management treatments. The study resulted that more added returns obtained from pendimethalin CS formulation $(1 \mathrm{~kg} / \mathrm{ha})$, $\mathrm{PE}+$ One hoeing 35 DAS treatment plot compared to rest of all other treatment plots (Table 3). The weed free plot was record higher grain yield, but it was economically similar to the treatment pendimethalin CS formulation (1 kg/ha), PE + One hoeing 35 DAS. This was mainly due to higher gross return along with lesser cost of cultivation especially, weed management cost. Similar result was reported by Rathod et al., (2016).

From the present investigation concluded that application of pendimethalin CS formulation (1 kg/ha), PE + One hoeing 35 DAS is economically viable and best alternative for controlling weeds and acquiring optimum seed yield of chickpea during rabi season in
Bihar.

\section{References}

Anonymous. 2018. Department of Agriculture Cooperation \& Farmers Welfare, Bihar.

Bhalla CS, Kurchania SP and Paradkar NR. 1998. Hebicidal weed control in chickpea (Cicer arietinum L.). World Weeds5: 121-124.

Gomez KA and Gomez AA. 1984. Statistical Procedures for Agricultural Research. $J$. Wiley and Sons, Singapore.

Goud VV, Murade NB, Khakre MS and Patil AN. 2013. Efficacy of imazethapyr and quizalofop-ethyl herbicides on growth and yieldof chickpea. The Bioscan8(3): 10151018.

Hoseiny RM and Jagannath S. 2011. E ffect of herbicide imazethapyr (pursuitTM) on chickpea seed germination. Archives of Phytopathology and Plant Protection44(3): $224-230$

Patel BD, Patel VJ, Patel JB and Patel RB. 2006. Effect of fertilizers and weed management practices on weed control in chickpea (Cicer arietinum L.) under middle Gujarat conditions. Indian Journal Crop Science, 1(1-2): 180-183

Pedde KC, Gore AK and Chavan AS. 2013. Integrated weed management in chickpea. Indian Journal of Weed Science, 45: 299.

Rathod PS, Patil DH and Dodamani BM. 2016. Integrated weed management in chickpea (Cicer arietinum L.) under rainfed conditions of Karnataka, India. Legume Research, 40(3): 580-585

Ratnam M, Rao AS and Reddy TY. 2011. Integrated Weed Management in Chickpea (Cicer arietinum L.). Indian Journal of Weed Science 43: 70-72.

Singh S, Walia US and Singh B. 2008. Effective control of weeds in chickpea. Indian Journal of Weed Science, 40(1\&2): 31-55.

\section{How to cite this article:}

Devendra Singh, S. Pazhanisamy, Sunil Kumar, Amrendra Kumar and Sai Linga Reddy. 2020. Bio- efficacy of Different Herbicides in Broad Spectrum Weed Management for Chickpea. Int.J.Curr.Microbiol.App.Sci. 9(03): 2313-2317. doi: https://doi.org/10.20546/ijcmas.2020.903.262 